Jurnal

Kardiologi Indonesia

J Kardiol Indones. 20I5;36:14-2 I

ISSN $0126 / 3773$

Clinical Research

\title{
Does Albuminuria Correlate With Silent Myocardial Ischemia And Delayed Heart Rate Recovery In Hypertensive Men Without Diabetes Mellitus?
}

\author{
Johan Winata, A. Lucia Panda, R. Abd. Azis
}

Departement of Cardiology and vascular Medicine Faculty of Medicine Universitas Sam Ratulangi
Background: Silent myocardial ischemia (SMI) defined asmyocardial ischemiawithout anginal pain. SMI is frequently found in diabetes due to autonomic neuropathy, but in hypertension the involvement of autonomic neuropathy is still not known. Heart rate recovery(HRR) has been known as manifestation of autonomic neuropathy. The simple measurement of HRR is potential as screening tools for autonomic neuropathy. Nevertheless, SMI and delayed HRR are known as independent predictors for cardiovasluar mortality, hence emphasize the importance for early diagnosis. In diabetes, albuminuria has been proven to be an independent predictor for SMI and delayed HRR, but in hypertensive patients without diabetes the correlation is still unclear.

Objectives: This study is aimed to determine the incidence of SMI, delayed HRR, and albuminuria in hypertensive patients without diabetes, the correlation between albuminuria and SMI and delayed HRR.

Methods: This is an observational study with cross-sectional approach. Fourty consecutive hypertensive without diabetes, history of chest pain, and known CAD. They underwent treadmill exercise testing with collection of spot urine before exercise to measure albumin urine to creatinine ratio (ACR). SMI and HRR to 3 minutes were then recorded.

Results: SMI was diagnosed in I5\% patients. The incidence of delayed HRR in the first, second and third minute after peak exercise were $60 \%, 80 \%$, and $52.5 \%$ respectively. Albuminuria was significantly associated with SMI (OR I 3.889 (I.423 - I 35.544), $p=0.014$ ). There were no signification correlation between albuminuria and delayed HRR

Conclusion: Albuminuria is a good predictor for SMI in hypertensive patients.

(J Kardiol Indones. 20I5;36:I4-2I)

Keywords: Silent myocardial ischemia, heart rate recovery, autonomic neuropathy, albuminuria 
Jurnal

\title{
Hubungan Albuminuria dengan Silent Myocardial Ischemia dan Keterlambatan Heart Rate Recovery pada Subjek Pria Hipertensi Tanpa Diabetes Melitus
}

\author{
Johan Winata, A. Lucia Panda, R. Abd. Azis
}

\begin{abstract}
Latar belakang: Silent myocardial ischemia (SMI) adalah iskemia miokard tanpa gejala angina. SMI sering ditemukan pada pasien diabetes melitus (DM) dan hipertensi. SMI pada DM dikaitkan dengan neuropati autonom (NA), sedangkan pada hipertensi keterlibatan NA belum diketahui. Heart rate recovery (HRR) merupakan manifestasi NA.SMI dan keterlambatan HRR berhubungan dengan peningkatan risiko kematian kardiovaskular, sehingga deteksi dini keduanya merupakan hal yang sangat penting. Albuminuria diketahui memiliki hubungan dengan SMI dan NA pada pasien DM, namun penelitian pada pasien hipertensi masih terbatas.

Tujuan: Penelitian ini ditujukan untuk mengetahui angka kejadian SMI, keterlambatan HRR, dan albuminuria, dan hubungan albuminuria dengan SMI dan keterlambatan HRR.

Metode: Desain yang digunakan pada penelitian ini adalah observasional dengan pendekatan potong lintang pada bulan September-Desember 2014 . Jumlah sampel adalah 40 orang laki-laki, usia 40-60 tahun dengan hipertensi tanpa DM. Semua subjek dilakukan pengambilan sampel urin sewaktu untuk pengukuran albumin urine to creatinine ratiodan pemeriksaan TST dengan protokol Bruce untuk mendeteksi SMI dan keterlambatan HRR menit ke-1 sampai menit ke-3. Albuminuria dan keterlambatan HRR menit ke-1 sampai ke-3 dinyatakan sebagai positif dan negatif sesuai dengan nilai ambang.

Hasil: Angka kejadian SMI sebesar 15\%, keterlambatan HRR menit ke-1 sebesar 60\%, keterlambatan HRR menit ke-2 sebesar 80\%, dan keterlambatan HRR menit ke-3 sebesar 52.5\%. Ditemukan hubungan bermakna antara albuminuria dengan SMI positif (OR 13.889 (IK 95\% 1.423 - 135.544), $\mathrm{p}=0.014$ ). Tidak ditemukan hubungan bermakna antara albuminuria dengan keterlambatan HRR menit ke-1 sampai menit ke-3.

Kesimpulan: Albuminuria merupakan prediktor SMI pada pasien hipertensi tanpa DM.
\end{abstract}

(J Kardiol Indones. 2015;36:14-21)

Kata kunci: Silent myocardial ischemia, heart rate recovery, neuropati autonom, albuminuria

\section{Alamat Korespondensi}

dr. Johan Winata. Bagian Ilmu Penyakit Jantung dan Pembuluh Darah, Fakultas Kedokteran Universitas Sam Ratulangi Manado, Cardiovascular and Brain Center RSU Prof. dr. RD. Kandou, Manado, E-mail: winata.johan@gmail.com

\section{Latar belakang}

Hipertensi merupakan faktor risiko yang sangat penting untuk penyakit jantung koroner (PJK). ${ }^{1,2} \mathrm{PJK}$ menyebabkan perfusi miokard menjadi terganggu dan menimbulkan iskemia. Pada sebagian besar kasus, iskemia miokard akan menimbulkan gejala 
angina pektoris; namun pada populasi diabetes melitus dan hipertensi, seringkali iskemia miokard tidak menimbulkan gejala yang dikenal dengan silent myocardial ischemia (SMI). Pada beberapa literatur didapatkan hal yang sangat menarik, yaitu angka kejadian SMI pada pasien hipertensi dilaporkan menyerupai populasi DM, yaitu berkisar antara 15$57 \% .^{3}$

Pada pasien DM, SMI disebabkan oleh neuropati autonom (NA), ${ }^{4}$ namun pada pasien hipertensi ambang batas nyeri yang meningkat ditengarai menjadi penyebab, sedangkan peranan NA belum pernah diteliti. ${ }^{3}$ Sebuah studi oleh Ayad dkk dengan populasi penelitian pasien DM tipe I dan II menunjukkan bahwa hipertensi merupakan faktor risiko independen terhadap NA. ${ }^{5}$

Beberapa studi literatur menemukan hubungan NA dengan keterlambatan heart rate recovery (HRR) pada treadmill stress test pada pasien DM. ${ }^{6}$ Sebuah studi oleh Yamada dkk menunjukkan keterlambatan HRR merupakan prediktor untuk SMI pada pasien DM. ${ }^{7}$ Sacre dkk menetapkan nilai ambang HRR menit ke-1 sampai menit ke-3 untuk menentukan NA pada pasien DM tipe II. ${ }^{6}$ Pada pasien hipertensi, sebuah studi oleh Polonia dkk menunjukkan adanya disfungsi autonom pada pasien dengan keterlambatan HRR yang diduga disebabkan karena terganggunya reaktivasi vagal yang mengindikasikan adanya disfungsi autonom. ${ }^{8}$

Saat ini, albuminuria merupakan pemeriksaan yang paling sering dihubungkan dengan SMI dan NA pada pasien DM. Pada populasi umum. Beijers dkk menemukan hubungan antara albuminuria dengan $\mathrm{NA},{ }^{10}$ sedangkan studi pada pasien hipertensi masih sangat terbatas. ${ }^{11}$ SMI dan keterlambatan HRR sendiri telah diketahui sebagai prediktor mortalitas kardiovaskular yang independen, sehingga diagnosa dini menjadi sangat penting. ${ }^{10}$ Albuminuria diharapkan mampu menjadi prediktor SMI dan keterlambatan HRR pada pasien hipertensi tanpa DM. Penelitian ini ditujukan untuk mengetahui hubungan albuminuria dengan SMI dan keterlambatan HRR, sekaligus untuk mengetahui kegunaan albuminuria sebagai prediktor SMI dan keterlambatan HRR.

\section{Metode Penelitian}

Penelitian ini merupakan studi observasional analitik dengan pendekatan potong lintang. Sebanyak 40 orang pria hipertensi tanpa diabetes melitus, riwayat PJK, dan gejala nyeri dada, dengan usia 40-60 tahun dimasukkan sebagai subjek penelitian. Semua pasien diharuskan menjalani treadmill stress test (TST) untuk mengetahui adanya SMI dan dilakukan perekaman HRR pada menit ke-1 sampai ke-3. SMI positif dinyatakan sebagai hasil TST positif tanpa gejala angina. Keterlambatan HRR dinyatakan positif dengan ambang batas: HRR menit ke- $1 \leq 28$ detak, HRR menit ke-2 $\leq 50$ detak, dan HRR menit ke-3 $\leq 52$ detak. ${ }^{5}$ Sebelum uji latih dilakukan pengumpulan urin sewaktu untuk pemeriksaan albuminuria dengan albumin urine to creatinine ratio (ACR) dengan menggunakan PEG enhanced imunoturbidimetric (Advia 1800). Albuminuria positif dinyatakan sebagai nilai ACR $\geq 20 \mathrm{mg} / \mathrm{g}^{.12}$

Treadmill stress test dilakukan dengan menggunakan CASE T2100 (GE medical system) dengan menggunakan protokol Bruce. Pasien dimotivasi untuk mencapai detak jantung (heart rate/HR) maksimal. Pemeriksaan dihentikan minimal setelah targetHR tercapai (85\% prediksi HR maksimum sesuai usia) atau karena kelelahan, sesak nafas, kelelahan tungkai, tekanan darah sistolik (TDS) > $250 \mathrm{mmHg}$, takikardi ventrikel, atau perubahan elektrokardiografi (EKG) iskemia. ${ }^{13}$ HRR dihitung sebagai berikut : HRR menit ke-1 merupakan selisih HR puncak dengan HRR akhir menit ke-2, HRR menit ke-2 merupakan selisih HR puncak dengan HRR menit ke-2, HRR menit ke-3 merupakan selisih HR puncak dengan HRR menit ke- $3 .^{5}$

Analisis data dilakukan secara deskriptif untuk menggambarkan karakteristik subjek hipertensi dan angka kejadian SMI, keterlambatan HRR, dan albuminuria. Perbedaan karakteristik klinis pada kelompok dengan SMI positif dan negatif maupun pada kelompok dengan keterlambatan HRR positif dan negatif diuji dengan uji independent t-test untuk variabel dengan sebaran data normal dan uji MannWhitney U untuk variabel dengan sebaran data tidak normal. Normalitas data ditentukan menggunakan uji Kolmogorov-Smirnov. Hubungan albuminuria dengan SMI dan keterlambatan HRR menit ke-1 sampai menit ke-3 diuji dengan uji chi square. Untuk mengetahui nilai diagnostik albuminuria sebagai prediktor SMI dan HRR menit ke-1 sampai menit ke-3 digunakan kurva ROC, selanjutnya dilakukan perhitungan sensitivitas, spesifisitas, akurasi, nilai duga positif (postive predictive value/PPV), dan nilai duga negatif (negative predictive value/NPV). 


\section{Hasil Penelitian}

Hasil penelitian menunjukkan angka kejadian SMI positif sebesar $15 \%$ (6 pasien) dari total 40 orang subjek penelitian. Angka kejadian keterlambatan HRR pada penelitian ini sebesar masing-masing $60 \%$ pada parameter HRR menit ke-1, $80 \%$ pada parameter HRR menit ke-2, dan $52.5 \%$ pada parameter HRR menit ke-3. Albuminuria pada penelitian ini diddapatkan pada 12 pasien (30\%)dari total 40 orang subjek penelitian (Tabel 1).

Tabel 1. Frekuensi SMI, keterlambatan HRR menit ke-1 sampai menit ke-3, dan albuminuria positif dan negatif.

\begin{tabular}{lc}
\hline Variabel & Frekuensi \\
\hline SMI & $6(15 \%)$ \\
Keterlambatan HRR menit ke-1 & $24(60 \%)$ \\
Keterlambatan HRR menit ke-2 & $32(80 \%)$ \\
Keterlambatan HRR menit ke-3 & $21(52.5 \%)$ \\
Albuminuria & $12(30 \%)$ \\
\hline
\end{tabular}

Hasil uji statistik karakteristik klinis tidak menunjukkan adanya perbedaan bermakna antara rerata usia, IMT, lingkar pinggang, TDS, dan TDD pada kelompok dengan SMI positif dan negatif dan kelompok dengan keterlambatan HRR postif dan negatif.

Sebanyak 5 (83.3\%) orang pasien dengan SMI positif menunjukkan albuminuria positif. Sebanyak $9(26.5 \%)$ pasien dengan SMI negatif menunjukkan albuminuria positif. Hasil analisis ditemukan hubungan bermakna antara albuminuria dengan SMI (OR $13.889(1.423-135.544), \mathrm{p}=0.014)($ Tabel 4). Kurva ROC menunjukkan bahwa albuminuria mempunyai nilai diagnostik yang baik, dengan kurva menjauhi garis $50 \%$ dan mendekati $100 \%$ (Gambar 1). Nilai AUC yang diperoleh sebesar 78,4\% (IK 95\% $=58.8 \%$ $98.1 \%$ dengan $\mathrm{p}=0.028$ ). Uji diagnostik untuk nilai sensitivitas albuminuria menunjukkan nilai 73,3\% dan spesifitas $73.5 \%$. Akurasi ACR sebagai petanda SMI menunjukkan nilai $75 \%$ dengan positive predictive value (PPV) sebesar $35.7 \%$ dan negative predictive value (NPV) sebesar 96.2\% (Tabel 5).

Tabel 2. Karakteristik dasar sampel penelitian berdasarkan usia, IMT, lingkar pinggang, TDS, dan TDD pada kelompok SMI positif dan negatif

\begin{tabular}{lccc}
\hline Variabel & $\begin{array}{c}\text { SMI Positif } \\
\text { Mean } \pm \text { SD }\end{array}$ & $\begin{array}{c}\text { SMI Negatif } \\
\text { Mean } \pm \text { SD }\end{array}$ & P \\
\hline Usia (tahun) & $54.17 \pm 4.87$ & $53.50 \pm 5.32$ & 0.769 \\
IMT (kg/m2) & $26.74 \pm 2.63$ & $27.09 \pm 3.46$ & 0.784 \\
Lingkar Pinggang (cm) & $92.33 \pm 10.95$ & $92.68 \pm 8.83$ & 0.944 \\
Tekanan Darah Sistolik & $141.67 \pm 20.41$ & $131.76 \pm 18.50$ & 0.255 \\
Tekanan Darah Diastolik & $86.67 \pm 8.16$ & $87.92 \pm 8.50$ & 0.782 \\
\hline
\end{tabular}

Tabel 3. Karakteristik dasar sampel penelitian berdasarkan usia, IMT, lingkar pinggang, TDS, dan TDD pada kelompok dengan keterlambatan HRR menit ke-1 sampai ke-3

\begin{tabular}{|c|c|c|c|c|c|c|c|c|c|}
\hline \multirow{3}{*}{ Variabel } & \multicolumn{2}{|c|}{ HRR Menit ke-1 } & \multirow{3}{*}{$\mathrm{P}$} & \multicolumn{2}{|c|}{ HRR Menit ke-2 } & \multirow{3}{*}{$\mathrm{P}$} & \multicolumn{2}{|c|}{ HRR Menit ke-3 } & \multirow{3}{*}{$\mathrm{P}$} \\
\hline & $\leq 28$ detak & $>28$ detak & & $\leq 50$ detak & $>50$ detak & & $\leq 52$ detak & $>52$ detak & \\
\hline & Mean \pm SD & Mean \pm SD & & Mean $\pm S D$ & Mean $\pm S D$ & & Mean $\pm S D$ & Mean \pm SD & \\
\hline Usia (tahun) & $\begin{array}{c}53.63 \pm \\
5.35\end{array}$ & $53.56 \pm$ & 0971 & $54.41 \pm$ & $50.38 \pm$ & 051 & $\begin{array}{c}54.00 \pm \\
5.55\end{array}$ & $53.16 \pm$ & 0613 \\
\hline \multirow[b]{2}{*}{ IMT (kg/m2) } & $2776+$ & $25.94+$ & & $27.37+$ & $25.70+$ & & $27.43+$ & $26.60+$ & \\
\hline & 3.53 & 2.72 & 0.075 & $3.56^{2}$ & 1.67 & 0.249 & 4.19 & 2.00 & 0.435 \\
\hline \multirow{2}{*}{ Lingkar Pinggang $(\mathrm{cm})$} & $94.21 \pm$ & $90.25 \pm$ & & $93.47 \pm$ & $89.25 \pm$ & & $93.29 \pm$ & $91.84 \pm$ & \\
\hline & 9.46 & 8.03 & 0.164 & 9.53 & 5.89 & 0.249 & 10.43 & 7.37 & 0.627 \\
\hline Tekanan Darah & $134.58 \pm$ & $131.25 \pm$ & & $135.00 \pm$ & $126.25 \pm$ & & $133.81 \pm$ & $132.63 \pm$ & \\
\hline Sistolik (mmHg) & 19.10 & 18.93 & 0.613 & 19.34 & 15.98 & 0.235 & 18.02 & 20.23 & 0.872 \\
\hline Tekanan Darah & $86.67 \pm$ & $89.38 \pm$ & & $88.13 \pm$ & $86.25 \pm$ & & $87.14 \pm$ & $88.42 \pm$ & \\
\hline Diastolik (mmHg) & 8.68 & 7.72 & 0.255 & 8.59 & 7.44 & 0.654 & 8.45 & 8.34 & 0.611 \\
\hline
\end{tabular}




\section{ROC Curve}

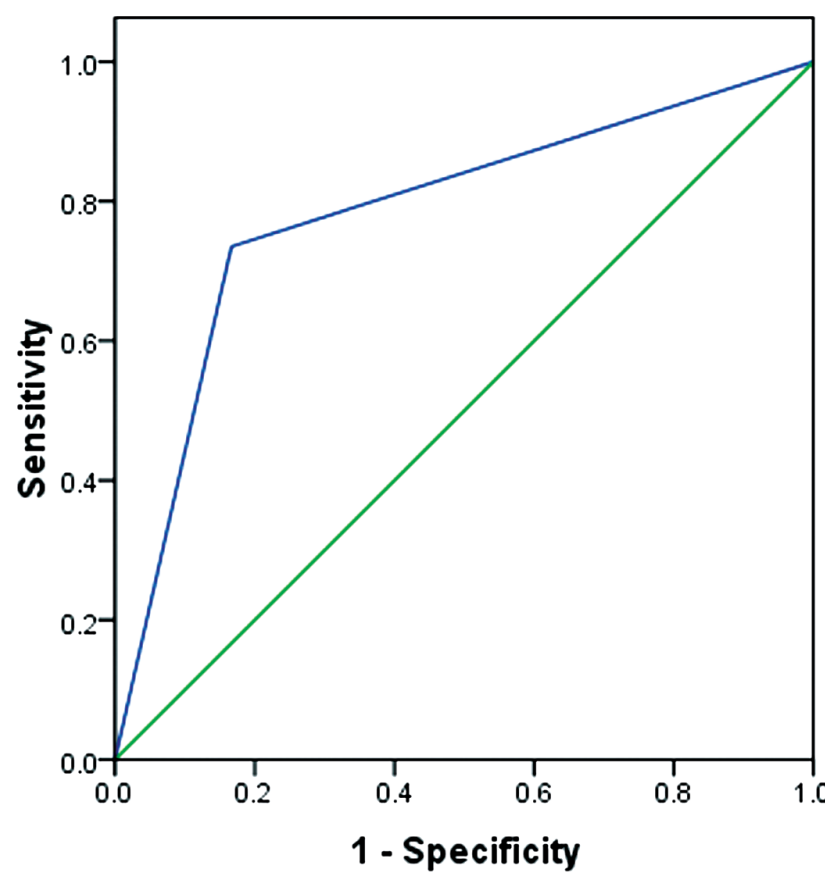

Gambar 1. ROC curve hubungan albuminuria dengan SMI
Hasil uji statistik untuk mengetahui hubungan albuminuria dengan keterlambatan HRR tidak menunjukkan hubungan bermakna antara albuminuria dengan keterlambatan HRR menit ke-1, HRR menit ke-2, dan HRR menit ke-3(Tabel 6).

Analisa hubungan HRR dengan SMI menunjukkan proporsi jumlah pasien dengan SMI positifyang lebih besar pada kelompok pasien dengan keterlambatan HRR menit ke-1 sampai ke-3, yaitu masing-masing $83.3 \%$ berbanding $55.9 \%, 100 \%$ berbanding $76.5 \%$, dan $66.7 \%$ berbanding $50 \%$, namun uji statistik tidak menunjukkan nilai signifikan dengan nilai $\mathrm{p}>0.05$ (Tabel 7).

\section{Diskusi}

Angka kejadian SMI pada populasi hipertensi tanpa diabetes melitus bervariasi antara $15-57 \%$ dengan pemeriksaan holter monitoring. ${ }^{3}$ Laporan mengenai skrining SMI dengan menggunakan TST masih jarang dilaporkan. Sampai saat ini belum ada laporan mengenai angka kejadian SMI pada populasi hipertensi di Indonesia.

Tabel 4. Uji Diagnostik dan distribusi albuminuria berdasarkan nilai ambang pada kelompok SMI dan tanpa SMI

\begin{tabular}{lcccc}
\hline & SMI Positif & SMI Negatif & OR & P \\
\hline Albuminuria Positif & $5(83.3 \%)$ & $9(26.5 \%)$ & \multirow{2}{*}{13.889} & \multirow{2}{*}{0.014} \\
Albuminuria Negatif & $1(16.7 \%)$ & $25(73.5 \%)$ & \\
\hline
\end{tabular}

Tabel 5. Hasil uji diagnostik albuminuria sebagai prediktor SMI

\begin{tabular}{lccccc}
\hline Marker & Sensitivitas & Spesifisitas & Akurasi & PPV & NPV \\
\hline Albuminuria & $83.3 \%$ & $73.5 \%$ & $75 \%$ & $35.7 \%$ & $96.2 \%$ \\
\hline
\end{tabular}

Tabel 6. Hubungan albuminuria dengan keterlambatan HRR menit ke-1, ke-2, dan ke-3

\begin{tabular}{|c|c|c|c|c|c|c|c|c|c|}
\hline & \multicolumn{2}{|c|}{ HRR Menit ke-1 } & \multirow{2}{*}{$P$} & \multicolumn{2}{|c|}{ HRR Menit ke-2 } & \multirow{2}{*}{ P } & \multicolumn{2}{|c|}{ HRR Menit ke-3 } & \multirow{2}{*}{$\mathrm{P}$} \\
\hline & $\leq 28$ detak & $>28$ detak & & $\leq 50$ detak & $>50$ detak & & $\leq 52$ detak & $>52$ detak & \\
\hline Albuminuria Positif & $8(33.3 \%)$ & $6(37.5 \%)$ & & $12(37.5 \%)$ & $2(25 \%)$ & & $6(28.6 \%)$ & $15(71.4 \%)$ & \\
\hline Albuminuria Negatif & $16(66.7 \%)$ & $10(62.5 \%)$ & & $20(62.5 \%)$ & $6(75 \%)$ & & $8(42.1 \%)$ & $11(57.9 \%)$ & 0.37 \\
\hline
\end{tabular}

Tabel 7. Uji Diagnostik dan distribusi SMI pada kelompok dengan dan tanpa keterlambatan HRR menit ke-1, ke-2, dan ke-3

\begin{tabular}{lcccc}
\hline HRR & & SMI Positif & SMI Negatif & P \\
\hline \multirow{2}{*}{ HRR Menit ke-1 } & $\leq 28$ detak & $5(83.3 \%)$ & $19(55.9 \%)$ & \multirow{2}{*}{0.212} \\
& $>28$ detak & $1(16.7 \%)$ & $15(44.1 \%)$ & \\
\multirow{2}{*}{ HRR Menit ke-2 } & $\leq 50$ detak & $6(100 \%)$ & $26(76.5 \%)$ & \multirow{2}{*}{0.236} \\
\hline \multirow{2}{*}{ HRR Menit ke-3 } & $>50$ detak & $0(0 \%)$ & $8(23.5 \%)$ & \\
& $\leq 52$ detak & $4(66.7 \%)$ & $17(50 \%)$ & \multirow{2}{*}{0.381} \\
\hline
\end{tabular}


Pada penelitian ini didapatkan angka kejadian SMI sebesar 15\%. Pada studi oleh Massie BM dkk, angka kejadian SMI dengan TST dilaporkan mencapai $37 \%$. Namun, pada studi dengan angiografi koroner, $39 \%$ diantaranya menampilkan arteri koroner yang normal. ${ }^{14}$ Penelitian lain oleh Pringle SD, dkk dengan subjek 90 pasien hipertensi dengan hipertrofi ventrikel kiri, 46 diantaranya menunjukkan SMI positif dari pemeriksaan holter monitoring. Namun, dari pemeriksaan TST hanya 26 pasien yang menampilkan hasil positif. Hasil ini kemudian dikonfirmasi dengan pemeriksaan thallium scanning dengan hasil 48 pasien memiliki reversible perfusion defects. ${ }^{14}$

Pada penelitian ini nilai diagnostik TST dalam menentukan pasien dengan hasil positif pasti tidak diketahui karena angiografi koroner ataupun myocardial perfusion scintigraphy (MPS) tidak dilakukan. Nilai sensitivitas dan spesisfisitas TST dalam mendeteksi iskemia miokard lebih inferior dibandingkan dengan pemeriksaan diagnostik lain seperti MPS dan angiografi koroner. ${ }^{13,14}$ Namun, faktor ketersediaan fasilitas masih menjadi kendala di Indonesia. Konfirmasi mengenai angka kejadian SMI dengan pemeriksaan yang lebih sensitif dan spesifik masih perlu untuk dilakukan untuk mengetahui angka kejadian yang lebih akurat.

Keterlambatan HRR dihubungkan dengan peningkatan risiko kardiovaskular pada DM, hipertensi, dan bahkan pada populasi normal. ${ }^{16-}$ ${ }^{19}$ Sebuah studi retrospektif oleh Hadley dkk dari data veteran di Amerika Serikat menunjukkan hubungan keterlambatan HRR dengan peningkatan mortalitas kardiovaskular. ${ }^{17}$ Sebuah studi oleh Polonia dkk mengungkapkan peranan disfungsi tonus parasimpatis pada pasien hipertensi dengan keterlambatan HRR, yang menekankan adanya disfungsi autonom pada pasien hipertensi. ${ }^{8}$ Studi epidemiologi yang mengukur HRR pada pasien hipertensi belum pernah dilakukan.

Pada penelitian ini peneliti menggunakan batasan keterlambatan HRR sesuai dengan studi yang dilakukan oleh Sacre dkk, dimana studi tersebut merupakan satu-satunya penelitian yang mengkonfirmasi validitas HRR berdasarkan pengujian 7 parameter sistem saraf autonom. Hal ini didasarkan pada pemikiran bahwa keterlambatan HRR disebabkan oleh neuropati autonom yang banyak terjadi pada pasien DM. Hasil penelitian oleh Sacre dkk berhasil menemukan batasan HRR menit ke-1 sampai menit ke-3 dengan sensitivitas dan spesifisitas yang berbeda, yaitu untuk HRR menit ke-1 sensitivitas 93\%, spesifisitas 69\%, HRR menit ke-2 sensitivitas $96 \%$ dan spesifisitas 63\%, dan HRR menit ke-3 sensitivitas 70\% dan spesifisitas $84 \%{ }^{6}$

Hasil dari penelitan saat ini didapatkan angka kejadian keterlambatan HRR pada menit ke-1, ke-2, dan ke-3 masing-masing adalah 60\% (24 pasien), $80 \%$ (32 pasien), dan 52,5\% (21 pasien). Temuan ini sesuai dengan sensitivitas dan spesifisitas masingmasing pengukuran pada menit ke-1 sampai ke-3, yaitu sensitivitas keterlambatan HRR menit ke-2 paling sensitif sehingga mampu menunjukkan nilai positif yang lebih tinggi dari nilai keterlambatan HRR menit ke-1dan ke-3, sedangkan keterlambatan HRR menit ke-3 yang paling spesifik namun kurang sensitif menunjukkan nilai positif yang lebih rendah dari nilai keterlambatan HRR menit ke-1 dan ke-2.

Angka kejadian keterlambatan HRR pada pasien hipertensi tanpa DM yang tinggi ini sangat menarik. Komponen keterlambatan HRR yang merupakan prediktor independen terhadap mortalitas kardiovaskular menawarkan aspek diagnostik dan terapi yang masih harus dipikirkan pada pasien hipertensi.

Hipertensi juga dihubungkan dengan albuminuria sebagai salah satu petanda gangguan ginjal. Angka kejadian albuminuria pada pasien hipertensi pada studi NHANES III sekitar $16 \% .{ }^{20}$ Pada studi oleh Marin dkk di Spanyol, angka kejadian albuminuria pada pasien hipertensi tanpa gangguan metabolisme glukosa adalah 39.4\%. ${ }^{21}$ Albuminuria juga dihubungkan dengan mortalitas kardiovaskular. Sebuah studi oleh Beijers dkk dengan sampel populasi umum dari ras Kaukasian usia 50-70 tahun berhasil menunjukkan bahwa albuminuria merupakan faktor risiko independen terhadap mortalitas kardiovaskular. ${ }^{10}$

Pada penelitian ini angka kejadian albuminuria adalah 30\% (12 pasien) dengan pengukuran menggunakan metode ACR dengan sampel urin sewaktu. Berbeda dengan populasi DM, saat ini pengukuran albuminuria bukan merupakan prosedur skrining yang rutin dilakukan pada pasien hipertensi. Beberapa data penelitian mengungkapkan bahwa penurunan tekanan darah optimal dapat menurunkan derajat albuminuria yang merupakan prediktor penting mortalitas kardiovaskular. ${ }^{49}$ Pengukuran ACR dengan sampel urin sewaktu yang lebih praktis diharapkan mampu memberikan pandangan baru mengenai tatalaksana penderita hipertensi. ${ }^{12}$

Hubungan SMI dengan albuminuria telah dibuktikan pada populasi DM, namun studi mengenai 
hubungan keduanya pada populasi hipertensi masih terbatas. Sebuah studi oleh Bianchi S dkk pada 42 subjek hipertensi dengan mikroalbuminuria dibandingkan dengan 42 subjek hipertensi tanpa albuminuria menunjukkan angka kejadian SMI yang lebih tinggi pada kelompok hipertensi dengan albuminuria, yaitu 7 pasien berbanding dengan hanya 1 pasien pada kelompok hipertensi tanpa albuminuria. ${ }^{11}$

Pada penelitian ini didapatkan hubungan yang bermakna antara albuminuria dengan SMI ( $\mathrm{p}=0.014)$ dengan odds ratio (OR) 13.889, yang berarti penderita hipertensi dengan albuminuria memiliki risiko 13.889 kali SMI positif dibandingkan penderita hipertensi tanpa albuminuria. Kurva ROC menunjukkan bahwa albuminuria mempunyai nilai diagnostik yang baik, dengan kurva menjauhi garis $50 \%$ dan mendekati $100 \%$. Nilai AUC yang diperoleh sebesar $78,4 \%$ (95\% CI 58.8\%-98.1\% dengan $\mathrm{p}=0.028)$. Dengan demikian, albuminuria dapat digunakan sebagai skrining pasien hipertensi tanpa gejala PJK untuk memprediksi adanya SMI positif.

Hubungan albuminuria dengan keterlambatan HRR pada pasien hipertensi tanpa DM belum pernah diteliti sebelumnya. Pada populasi DM, albuminuria berhubungan dengan adanya NA. Sebuah penelitan oleh Ayad dkk kemudian menemukan bahwa pasien hipertensi pada pasien DM merupakan faktor risiko independen yang memperparah derajat NA. ${ }^{5}$ Beberapa studi telah memvalidasi kepentingan keterlambatan HRR dengan neuropati autonom, termasuk studi oleh Sacre dkk. ${ }^{6}$ Namun, studi yang meneliti hubungan neuropati autonom yang diperiksa melalui keterlambatan HRR dengan albuminuria belum pernah dilakukan sampai saat ini.

Pada sebuah studi oleh Beijers dkk meneliti hubungan NA melalui pengukuran dengan 10 parameter sistem saraf autonom dengan albuminuria pada populasi umum, ditemukan hubungan lemah antara skor disfungsi autonom dengan albuminuria $(\beta$ $=0.16$ [95\% CI 0.01-0.33]). ${ }^{10}$ Pada penelitian ini tidak ditemukan hubungan bermakna antara albuminuria dengan keterlambatan HRR menit ke-1, menit ke-2, dan menit ke-3 dengan nilai $\mathrm{p}>0.05$.

Namun, terlepas dari tidak adanya hubungan antara mikroalbuminuria dan keterlambatan HRR, kedua komponen tersebut masing-masing memiliki kemaknaan klinis sebagai prediktor mortalitas kardiovaskular. Studi oleh Beijers dkk menunjukkan hubungan independen untuk mikroalbuminuria dan neuropati autonom dengan kematian kardiovaskular masing-masing dengan relative risk (RR) 2.13 (1.094.17) dan 1.76 (1.05-2.94). ${ }^{10}$

Dengan demikian, pengetahuan mengenai keterlambatan HRR pada pasien hipertensi tanpa DM belum sepenuhnya dimengerti dan memerlukan penelitan lebih lanjut mengenai faktor-faktor yang mempengaruhi. Mekanisme keterlambatan HRR harus mendapat perhatian khusus karena implikasinya terhadap kejadian kardiovaskular yang penting.

Pada studi oleh Yamada dkk dikethui bahwa keterlambatan HRR menit ke-1 merupakan prediktor SMI pada populasi DM tipe II.7 Pada penelitian ini didapatkan proporsi yang lebih besar adanya SMI positif pada kelompok pasien dengan keterlambatan HRR pada menit ke-1 sampai ke-3, yaitu masingmasing $83.3 \%$ berbanding $55.9 \%, 100 \%$ berbanding $76.5 \%$, dan $66.7 \%$ berbanding $50 \%$, namun uji diagnostik ketiganya tidak menunjukkan nilai signifikan (tabel 7). Hubungan yang tidak bermakna pada penelitian ini kemungkinan disebabkan karena jumlah sampel yang kurang.

\section{Kesimpulan}

Angka kejadian SMI, keterlambatan HRR, dan albuminuria ditemukan cukup tinggi pada populasi hipertensi tanpa DM. Nilai prognostik terhadap kematian kardiovaskular menekankan kepentingan klinis masingmasing. Albuminuria memiliki hubungan dengan SMI dan diharapkan mampu untuk menjadi prediktor yang baik untuk SMI. Skrining albuminuria pada populasi hipertensi tanpa DM perlu dipertimbangkan untuk penanganan pasien yang optimal.

\section{Daftar Pustaka}

1. Mclnnes GT. Hypertension and coronary artery disease: cause and effect. J Hypertens Suppl 1995; 13(2): S49-56.

2. Lawes CM, Bennett DA, Rodgers A. Blood pressure and coronary heart disease: a review of the evidence. Semin Vasc Med 2002; 2(4): 355-68.

3. Boon D, Piek JJ, Montfrans GA. Silent ischemia and hypertension. Journal of Hypertension 2000; 18(10): 1355-1364.

4. Boras J, Brkljacic N, Ljubicic A, Ljubic S. Silent ischemia and diabetes mellitus. Diabetologia Croatia 2010; 39(2): 57-65.

5. Ayad F, Belhadj M, Paries J, Attali JR, Valensi P. Association between cardiac autonomic neuropathy and hypertension and its potential influence on diabetic complications. Diabet Med 
2010; 27(7): 804-811

6. Sacre JW, Jellis CL, Coombes JS, Marwick TH. Diagnostic accuracy of heart-rate recovery after exercise in the assessment of diabetic autonomic neuropathy. Diabet Med 2012; 29(9): e312-320.

7. Yamada T, Yoshitama T, Makino K, Lee T, Saeki F. Heart rate recovery after exercise is a predictor of silent myocardial ischemia in patients with type 2 diabetes. Diabetes Care 2011; 34: 724-6.

8. Polonia J, Amaral C, Bertoquini S, Martins L. Attenuation of heart rate recovery after exercise in hypertensive patients with blunting of the nighttime blood pressure fall. Int J Cardiol 2006; 106(2): 238-43.

9. Rutter MK, Wahid ST, McComb JM, Marshall SM. Significance of Silent ischemia and microalbuminuria in predicting coronary events in asymptomatic patients with type 2 diabetes. JACC 2002; 40(1): 56-61.

10. Beijers H, Ferreira I, Stehouwer C. Microalbuminuria and cardiovascular autonomic dysfunction are independently associated with cardiovascular mortality : Evidence for distinct pathway. Diabetes Care 2009; 32(9): 1698-1703.

11. Bianchi S, Bigazzi R, Amoroso A, Campese VM. Silent ischemia is more prevalent among hypertensive patients with microalbuminuria and salt sensitivity. Journal of Human Hypertension 2003; 17: 13-20.

12. Gansevoort RT, Verhave JC, Hillege HL, et al. The validity of screening based on spot morning urine samples to detect subjects with microalbuminuria in the general population. Kidney International 2005; 67(94): S28-S35.

13. Cameron NE, Cotter MA. Metabolic and vascular factors in the pathogenesis of diabetic neuropathy. Diabetes 1997; 46(2): S31-S37.

14. Massie BM, Szlachcic Y, Tubau JF, O’Kelly BF, Mmon S, Chin
W. Scintigraphic and electrocardiographic evidence of silent coronary artery disease in asymptomatic hypertension : A casecontrol study. JACC 1993; 22(6): 1598-1606.

15. Pringle SD, Dunn FG, Tweddel AC, Martin W, Macfarlane PW, McKillop JH, et al. Symptomatic and silent myocardial ischaemia in hypertensive patients with left ventricular hypertrophy. Br Heart J 1992; 67(5): 377-382.

16. Best SA, Bivens TB, Palmer MD, Boyd KN, Galbreath MM, Okada $\mathrm{Y}$, et al. Heart rate recovery after maximal exercise is blunted in hypertensive seniors. J Appl Physiol 2014; 117(11): 1302-7.

17. Cheng YJ, Lauer MS, Earnest CP, et al. Heart rate recovery following maximal exercise testing as a predictor of cardiovascular disease and all cause mortality in men with diabetes. Diabetes Care 2003; 26: 2052-2057.

18. Hadley DM, Dewey FE, Freeman JV, Myers JN, Froelicher VF. Prediction of cardiovascular death using a novel heart rate recovery parameter. Med Sci Sports Exerc 2008; 40(6): 1072-9

19. Watanabe J, Thamilarasan M, Blackstone EH, Thomas JD, Lauer MS. Heart rate recovery immediately after treadmil exercise and left ventricular systolic dysfunction as predictors of mortality. Circulation 2001; 104: 1911-1916.

20. Palatini P. Prevalence and clinical correlates of microalbuminuria in stage 1 hypertension. Results from the Hypertension and Ambulatory Recording Venetia Study (HARVEST) study. Am J Hypertens 1996; 9: 334-341.

21. Marin R, Rodriguez P, Tranche S, Redon J, Morales-Olivas F, Galgo A, et al. Prevalence of abnormal urinary albumin excretion rate in hypertensive patients with impaired fasting glucose and its association with cardiovascular disease. J Am Soc Nephrol 2006. 17(12 suppl 3): S178-88

22. Rodicio JL, Campo C, Ruilope LM. Microalbuminuria in essential hypertension. Kidney International 1998; 54: S51-4 